Session 2275

\title{
The Tenure and Promotion Dilemma at the Nation's Professional Schools of Engineering
}

\author{
Thomas G. Stanford and Donald A. Keating \\ University of South Carolina \\ Columbia, SC 29208 \\ Donna J. Michalek \\ Michigan Technological University \\ Houghton, MI 49931
}

\begin{abstract}
With today's emphasis on research at the nation's engineering schools, there exists an incongruence between graduate research and professionally oriented engineering education to enhance creative engineering practice for responsible leadership of new technology development and innovation. This paper presents the dilemma at the nation's engineering schools: to achieve excellence in both graduate research-oriented education and graduate professional education for the nation's engineers. At present, the nation's graduate education policy in engineering is a byproduct of research. Consequently, the tenure and promotion policy at the nation's engineering schools is primarily oriented toward research and dissemination of new scientific knowledge through publication. This paper presents the need for a transformation of the tenure and promotion criteria at the nation's engineering schools in order to develop a graduate professionaloriented alternative for those faculty who are innovating practice-oriented engineering education to improve U.S. technological competitiveness. This paper is based on two premises: first, that the nation's engineering schools play a vital role in shaping the nation's technology policy and educational policy, and second, that faculty who make needed practice-oriented educational innovation at the nation's engineering schools must be rewarded for their valuable and important contribution to the advancement of professional engineering education.
\end{abstract}

\section{Framing the Issues}

While graduate science research education in the United States has served the nation well in the education and training of future scientific researchers and university teachers, there is broad recognition that graduate engineering education must change to meet new challenges in the development of engineers for technology innovation in industry. As Morita, ${ }^{1}$ Chairman of Sony Corporation points out ... "The challenge for all countries, not just ours, is management of new technologies, new development, new products. We will need a lot of new ideas. Technology management will be the key to success for companies anywhere in the world in the coming years. 
Knowing how to make the best use of your engineers will be a test of whether a company will succeed in the coming age."

Over the long term, the nation's posture in scientific progress and technological progress parallels higher education's support of that which promotes the future strength of the nation's graduate scientific research manpower base for science, as well as equally important support of that which promotes the future strength of the nation's graduate professional engineering manpower base for technology. Of the two different activities, America's slip and loss of momentum has not been in scientific research and its dissemination. However, it is now evident that America's technology thrust for civilian and peacetime economy must be strengthened. The challenge is improving technology competitiveness and revitalizing graduate professional education to develop alternative educational paths of excellence for the nation's engineers as we have done in the past for the nation's scientific researchers.

The existing policy for science in the United States was basically set in motion over 50 years ago by the Bush ${ }^{2}$ report to the president, "Science - The Endless Frontier." This report was a landmark, and it set the stage for national investment in postwar scientific research and graduate research-oriented education which led to America's rise in graduate science research, but also contributed partially to its decline over three decades in civilian-oriented technology competitiveness.

However, Japan, which was devastated during World War II, rebuilt its civilian-oriented technology competitiveness largely on Demming's model for needs-driven continuous improvement which is, and has always been, the engineering method for needs-driven creative technology development. After three decades, the results of which model is more correct are convincing. Today, Demming is the talk of the town, but higher education at the nation's engineering schools is still primarily tied to the singular research-oriented model. There, the goals are viewed primarily as research for the discovery and dissemination of new scientific knowledge and the education of future teachers and researchers.

Although the Bush plan has proven to be correct for excellence in graduate science research and graduate science education, to promote the nation's scientific progress, it is fundamentally in error for development of the nation's technology and graduate professional engineering education to promote technology progress to meet real-world hopes, wants, and needs of people. If America is to regain its place of technology leadership in the global economy, then a change in graduate professional education of engineers is required.

\section{Engineering Professional Education and Technology Policy}

The development of human resources is essential to meeting the fundamental challenges in science and technology for a new era. ${ }^{3}$ It is also recognized that the generation, creation, development, and leadership of needs-driven technology innovation is primarily dependent on that group of men and women in industry and government service in responsible professional charge, who understand engineering and the fundamental laws of nature and are skilled in the 
techniques of creative engineering development and responsible professional leadership - the nation's professional engineers.

Consequently, it is now apparent, as it is with the development of human resources for scientific progress, that we shall have rapid or slow technological progress depending on the number of highly qualified and trained engineers developing technology and leading the process of innovation, their effective support, use, and leadership in industry, and the opportunity for further graduate professional education at the nation's universities to nurture and help these engineers to grow to their creative and leadership potential beyond entry level in engineering practice. It is now evident, therefore, that the national educational policy and national technology policy are directly linked together.

However, a major "educational gap" has existed for several years in graduate professional education of the nation's professional engineers which affects the nation's future technological progress. During the last three decades, American engineering education at the graduate level has been patterned after the scientific research model. Graduate research education, funding, research-oriented faculty, and curricula to enrich the graduate scientific research path has largely been built into the nation's engineering schools during the 60's, 70's and 80's.

The universities have performed an outstanding job in meeting their educational and research goal of training the nation's graduate scientists. The traditional graduate program is primarily geared to the resident student and, at the doctoral level, emphasizes preparation for entry level into research and teaching. Those engineers who wish to pursue graduate research career patterns have been especially well served.

However, after three decades the seriousness of the existing graduate professional educational gap and the resulting effects have now shown up in U. S. technology competitiveness in the global economy. As pointed out in the 1995 National Academy of Sciences report ${ }^{4}$ "Reshaping the Graduate Education of Scientists and Engineers," it is now apparent that the graduate education of engineers is largely a by-product of research. In effect, there is no policy for the graduate professional education of the nation's engineers as there is for the nation's scientists. As Walker, ${ }^{5}$ president emeritus of Pennsylvania State University and former chairman of the National Science Foundation, pointer out in 1978 - "Teaching research isn't teaching Engineering." Research and needs-driven creative engineering are two entirely different activities. "The key idea is that engineering is a system of management that results in the satisfaction of human needs ... The effectiveness of an engineer is measured by how well he or she invents and innovates to meet these needs."

The seriousness of the nation's lack of policy for development of human resources in creative engineering is further signaled by the report "Picking Up the Pace,"6 to rebuild competitiveness: "... Because technology is a driving force behind productivity improvements, export strength and a high standard of living, the stakes are enormous. Part of the reason for the erosion of America's technological lead is that we have tended to view progress in science and technology as a relay race from a "research-driven" model of the innovation process. The model views innovation as a linear process - starting with a major scientific breakthrough ... Consequently, this model 
emphasizes the importance of basic research.

A new model has emerged, however, and America's current difficulties in the global technology race have occurred, in part, because neither U. S. industry nor the federal government has responded sufficiently to that new reality.

In staking out a forceful role in the advancement of scientific knowledge, the government has tended to ignore technology. America assumed that government support for science would be adequate to provide for technology. It is not. Today, the nation is paying the price for that complacency."

\section{Reshaping the Graduate Education of Engineers: The Tenure and Promotion Dilemma and the Dual-Path Solution}

We thus see that a transformation in graduate professional education for engineers is required if America is to regain its technological edge. The emerging model is based on the premise that graduate engineering education should focus on the engineering method for needs-driven creative technology development. But if this model is to be adopted, it poses, among other things, a tenure and promotion dilemma for the nation's engineering schools.

It is apparent today that tenure and promotion policies in place at the nation's engineering schools reflect an award and reward structure based on the science-driven model of engineering education. Tenure and promotion criteria at many schools of engineering reveal an emphasis on research funding and publication. ${ }^{7,8}$ Such emphasis is expected if strong research faculty are to be attracted and retained. However, the same emphasis does not allow for development of the emerging model of professional engineering education.

It is important that tenure and promotion policies at the nation's schools of engineering be modified to provide recognition for those faculty who wish to engage in the practice of technology innovation and who make the needed practice-oriented educational innovation. Clearly, without such changes it will be impossible attract the strong professional-practice oriented engineering faculty who are so important to America's technological future.

Recognizing the reluctance which engineering college administrators will have to move from the science-driven model to the needs-driven model of graduate engineering education, a logical modification to current tenure and promotion policies would be the addition of a dual path for faculty who have interest in educational issues associated with leadership of technology innovation and development. Such a proposal has merit and is not without precedent. In adopting such a course of action, care must be taken to not slight one path at the expense of the other. Both will surely have a useful place in tenure and promotion policy for the foreseeable future and both groups of faculty can work together synergistically for mutual benefit.

While changes in engineering education will be met with reluctance and the modification to tenure and promotion policies proposed here will not be universally accepted, we, as engineering educators, must be visionary. A transformation in engineering education and its associated tenure and promotion policies for engineering faculty is required if America is to maintain its place in 
the world in the $21^{\text {st }}$ century.

\section{References}

1. Morita, A., 1986, "Made in Japan," E. P. Dutton, New York.

2. Bush, V., 1945, "Science - The Endless Frontier," Office of Scientific Research and Development, Washington, D. C.

3. National Academy of Sciences, 1993, "Science, Technology and the Federal Government," National Academy Press, Washington, D. C.

4. National Academy of Sciences, 1995, "Reshaping the Graduate Education of Scientists and Engineers," National Academy Press, Washington, D. C.

5. Walker, E., January 1978, Teaching Research Isn't Teaching Engineering," Engineering Education, 303307.

6. Council on Competitiveness, 1988, "Picking Up The Pace," Office of Council on Competitiveness, Washington, D. C.

7. $\quad$ Reis, R. M., March 1997, "The Tenure Journey,"

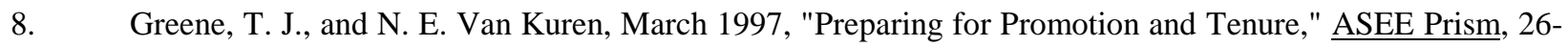
29.

\section{Authors}

THOMAS G. STANFORD received his Ph.D. in Chemical Engineering from the University of Michigan. He is currently an Assistant Professor of Chemical Engineering at the University of South Carolina teaching in the areas of thermodynamics and chemical process design.

DONALD A. KEATING received his M. Engr. degree in Mechanical Engineering from Cornell University. He is currently an Associate Professor of Mechanical Engineering teaching in the areas of mechanical engineering design and leadership of technology.

DONNA J. MICHALEK received her Ph.D in Mechanical Engineering from the University of Texas at Arlington. She is currently an Assistant Professor Mechanical Engineering. Her research interests are in the areas of computational fluid mechanics and algorithm development. 